\title{
PENGGUNAAN METODE PEMBELAJARAN GROUP INVESTIGATION UNTUK PENGAJARAN MATEMATIKA
}

\author{
Anny Widayanti ${ }^{1)}$ \\ 1) Sekolah Dasar Negeri Mororejo Jepara \\ Jl. Raya Mororejo KM 3 Kecamatan Mlonggo, Jepara, Jawa Tengah 59452 \\ Email: annywidayanti@gmail.com
}

\begin{abstract}
ABSTRAK
Berdasarkan pengamatan bahwa hasil Ujian Nasional mata pelajaran matematika menduduki ranking terendah dibandingkan dengan mata pelajaran yang lain. Demikian pula yang dialami selama ini dalam pembelajaran matematika di Sekolah Dasar Negeri Mororejo melalui hasil tes formatif, tes mid semester, maupun tes sumatif hasilnya menduduki rangking terendah dibanding dengan mata pelajaran yang lain. Tujuan dari penelitian ini adalah: Mendiskripsikan cara yang efektif dalam pembelajaran matematika tentang menyajikan data ke bentuk tabel, diagram, diagram garis, batang dan lingkaran melalui model pembelajaran group investigation dan membangkitkan motivasi siswa untuk pelajaran matematika. Metode yang digunakan adalah Penelitian Tindakan Kelas. Pelaksanaan penelitian ini dilaksanakan dalam dua siklus masingmasing siklus melalui empat tahap yaitu: tahap perencanaan, tahap pelaksanaan, tahap pengumpulan data, dan tahap refleksi. Pada pelaksanaan pembelajaran pada prasiklus yang hasilnya sangat rendah sebab dari 25 siswa setelah diadakan tes formatif terdapat 11 siswa yang mencapai tingkat ketuntasan belajar (44\%). Pada pelaksanaan pembelajaran siklus 1 setelah hasil belajar siswa dianalisis melalui hasil monitoring selama tindakan berlangsung menunjukkan ada 18 siswa telah mampu menguasai materi yang disampaikan dengan baik atau telah mencapai tingkat ketuntasan belajar (72\%). Pada siklus 2 terdapat 24 siswa telah mampu mencapai tingkat ketuntasan belajar (96 \%) dan 1 siswa belum mampu mencapai tingkat ketuntasan belajar (4 \%). Melihat hasil belajar siswa pada siklus 2 nampak sudah melebihi batas kriteria ketuntasan minimal lebih dari 70 .
\end{abstract}

Kata kunci: hasil belajar, diagram, model pembelajaran group investigation.

\section{PENDAHULUAN}

\section{Latar Belakang}

Kemajuan ilmu pendidikan semakin pesat menuntut sumber daya manusia (SDM) yang berkualitas. Untuk meningkatkan SDM tersebut, tentunya mutu pendidikan harus ditingkatkan. Permasalahan yang ada dalam dunia pendidikan formal bertambah dari tahun ke tahun. Salah satu permasalahan utama yang dihadapi bangsa Indonesia adalah, rendahnya mutu pendidikan formal pada setiap jenjang pendidikan. Usaha telah dilakukan untuk meningkatkan mutu pendidikan nasional, antara lain melalui berbagai pelatihan dan peningkatan kompetensi guru, pengadaan buku dan alat pembelajaran, perbaikan sarana dan prasarana pendidikan, dan peningkatan mutu manajemen sekolah. Namun demikian berbagai indikator mutu pendidikan belum menunjukkan peningkatan yang berarti. Pada hakikatnya pengalaman belajar memberikan pengalaman kepada siswa untuk menguasai kompetensi dasar secara ilmiah dan ditinjau dari dimensi kompetensi yang ingin dicapai, pengalaman belajar meliputi pengalaman untuk mencapai kompetensi pada ranah 
kognitif, afektif, dan psikomotorik. Penerapan metode pembelajaran dengan menggunakan alat peraga, khususnya bidang studi matematika didasari kenyataan, bahwa pada bidang studi matematika terdapat banyak pokok bahasan yang memerlukan alat bantu untuk menjabarkannya, diantaranya pada materi operasi bilangan bulat dengan pokok bahasan penjumlahan dan pengurangan. Oleh sebab itu, pembelajaran dengan menggunakan alat peraga dalam pokok bahasan tersebut dianggap sangat tepat untuk membantu mempermudah siswa memahami materi. Disisi lain suasana belajar akan lebih hidup, dan komunikasi antara guru dan siswa dapat terjalin dengan baik. Hal ini dapat membantu siswa dalam upaya meningkatkan prestasi belajar pada bidang studi matematika.

Pembelajaran matematika merupakan mata pelajaran yang sulit dan menjadi momok bagi sebagian besar siswa. Hal ini disebabkan karena pelajaran matematika merupakan mata pelajaran yang mempunyai karakteristik khusus, antara lain abstrak, deduktif, dan logis. Keabstrakan pelajaran matematika disebabkan karena objek dasarnya abstrak yaitu fakta, konsep, operasi, dan memiliki prinsip. Karena keabstrakan inilah yang menjadi mata pelajaran matematika tidak mudah untuk dipelajari, namun bukan berarti merupakan mata pelajaran yang sulit. Banyak para siswa membenci mata pelajaran matematika karena dianggap sebagai mata pelajaran yang sulit dan menakutkan. Padahal sekarang ini tidak dapat dipungkiri bahwa perkembangan pembelajaran matematika sangat berpengaruh terhadap kemajuan ilmu pengetahuan dan teknologi. Hal itu disebabkan mata pelajaran matematika sangat berguna dan dibutuhkan dalam semua aspek kehidupan manusia, sehingga penulis sebagai pendidik berusaha membuat siswa mau belajar dan menyukai mata pelajaran matematika. Kenyataan yang ada, dapat dilihat melalui hasil Ujian Nasional mata pelajaran matematika menduduki ranking terendah dibandingkan dengan mata pelajaran yang lain. Demikian pula dapat dialami oleh penulis selama ini dalam pembelajaran matematika di SD Negeri Mororejo melalui hasil tes formatif, tes mid semester, maupun tes sumatif hasilnya menduduki rangking terendah dibanding dengan mata pelajaran yang lain.

Adapun perbaikan pembelajaran yang penulis lakukan melalui Penelitian Tindakan Kelas (PTK) pada Mata Pelajaran Matematika secara khusus bertujuan: a) Mendiskripsikan cara yang efektif dalam pembelajraran matematika tentang menyajikan data ke bentuk tabel, diagram, diagram garis, batang dan lingkaran dengan model pembelajaran group investigation. $b$ ) Meningkatkan hasil belajar siswa menyajikan data ke bentuk tabel, diagram, diagram garis, batang dan lingkaran dengan model pembelajaran group investigation. c) Membangkitkan motivasi siswa untuk pelajaran matematika tentang menyajikan data ke bentuk tabel, diagram, diagram garis, batang dan lingkaran melalui model pembelajaran group investigation.

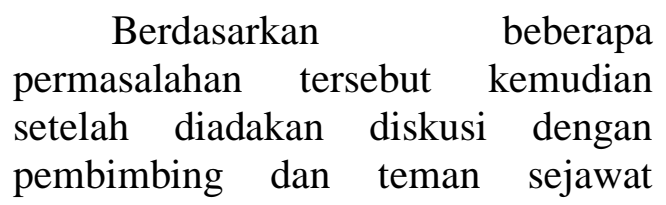


ditemukan faktor penyebab rendahnya prestasi belajar siswa dalam meningkatkan pengetahuan siswa terhadap menyederhanakan dan mengurutkan pecahan adalah : Apakah model pembelajaran group investigation dapat meningkatkan pengetahuan dan penguasaan siswa kelas VI SD Negeri Mororejo Kecamatan Mlonggo Kabupaten Jepara tentang menyajikan data ke bentuk tabel, diagram, diagram garis, batang dan lingkaran.

\section{TINJAUAN PUSTAKA}

Hasil belajar yang dicapai siswa dipengaruhi oleh dua faktor yakni faktor dari dalam diri siswa dan faktor dari luar diri siswa (Sudjana, 1989: 39). Dari pendapat ini faktor yang dimaksud adalah faktor dalam diri siswa perubahan kemampuan yang dimilikinya seperti yang dikemukakan oleh Clark (1981: 21) menyatakan bahwa hasil belajar siswa di sekolah $70 \%$ dipengaruhi oleh kemampuan siswa dan $30 \%$ dipengaruhi oleh lingkungan. Demikian juga faktor dari luar diri siswa yakni lingkungan yang paling dominan berupa kualitas pembelajaran (Sudjana, 2002: 39).

Hasil belajar siswa dipengaruhi oleh kamampuan siswa dan kualitas pengajaran. Kualitas pengajaran yang dimaksud adalah profesional yang dimiliki oleh guru. Artinya kemampuan dasar guru baik di bidang kognitif (intelektual), bidang sikap (afektif) dan bidang perilaku (psikomotorik).

Menurut Wina Sanjaya (2008) keberhasilan pembelajaran tidak sematamata tergantung pada kemampuan guru dalam merencanakan atau mendesain pembelajaran itu sendiri karena seorang guru dituntut mampu memahami tentang kurikulum yang sedang berlaku, di samping karakteristik siswa sebagai modal bagi seorang guru dalam menyampaikan sejumlah pengetahuan kepada siswa, demikian juga tidak kalah pentingnya fasilitas dan sumber daya yang ada ikut mewarnai keberhasilan suatu proses pembelajaran. Dalam hal ini kualitas seorang guru seperti latar belakang pendidikan dan pengalaman keprofesionalan, termasuk di dalamnya sikap guru terhadap siswa, intelegensi, motivasi dan kemampuan dalam pengelolaan pembelajaran.

Model pembelajaran Group Investigationn merupakan salah satu bentuk model pembelajaran kooperatif yang menekankan pada partisipasi dan aktivitas siswa untuk mencari sendiri materi (informasi) pelajaran yang akan dipelajari melalui bahan-bahan yang tersedia, misalnya dari buku pelajaran atau siswa dapat mencari melalui internet. Siswa dilibatkan sejak perencanaan, baik dalam menentukan topik maupun cara untuk mempelajarinya melalui investigasi. Tipe ini menuntut para siswa untuk memiliki kemampuan yang baik dalam berkomunikasi maupun dalam keterampilan proses kelompok. Model Group Investigation dapat melatih siswa untuk menumbuhkan kemampuan berfikir mandiri. Keterlibatan siswa secara aktif dapat terlihat mulai dari tahap pertama sampai tahap akhir pembelajaran.

Dalam model Group Investigation terdapat tiga konsep utama, yaitu: penelitian atau enquiri, pengetahuan atau knowledge, dan dinamika kelompok atau the dynamic of the learning group, (Udin S. Winaputra, 2001: 75). Penelitian di sini adalah proses dinamika siswa memberikan respon terhadap masalah dan memecahkan masalah tersebut. Pengetahuan adalah pengalaman belajar yang diperoleh siswa baik secara langsung maupun tidak langsung. Sedangkan dinamika kelompok menunjukkan suasana yang menggambarkan sekelompok saling berinteraksi yang melibatkan berbagai ide dan pendapat serta saling bertukar pengalaman melaui proses saling beragumentasi. 
Matematika merupakan ilmu universal yang mendasari perkembangan teknologi modern, mempunyai peran penting dalam berbagai disiplin dan memajukan daya pikir manusia. Perkembangan pesat di bidang teknologi informasi dan komunikasi dewasa ini dilandasi oleh perkembangan matematika di bidang teori bilangan, aljabar, analisis, teori peluang dan matematika diskrit. Untuk menguasai mencipta teknologi di masa mendatang diperlukan penguasaan yang kuat sejak dini (BNSP, 2007 :10).

Mata pelajaran Matematika perlu diberikan kepada semua peserta didik mulai dari sekolah dasar untuk membekali peserta didik dengan kemampuan berpikir logis, analitis, sistematis, kritis, dan kreatif, serta kemampuan bekerjasama. Kompetensi tersebut diperlukan agar peserta didik dapat memiliki kemampuan memperoleh, mengelola, dan memanfaatkan informasi untuk bertahan hidup pada keadaan yang selalu berubah, tidak pasti, dan kompetitif.

Mata Pelajaran Matematika bertujuan agar peserta didik memiliki kemampuan sebagai berikut: a) Memahami konsep matematika, menjelaskan keterkaitan antarkonsep dan mengaplikasikan konsep atau algoritma, secara luwes, akurat, efisien, dan tepat dalam pemecahan masalah. b) Menggunakan penalaran pada pola dan sifat, melakukan manipulasi Matematika dalam membuat generalisasi, menyusun bukti, atau menjelaskan gagasan dan pernyataan Matematika. c) Memecahkan masalah yang meliputi kemampuan memahami masalah, merancang model Matematika, menyelesaikan model dan menafsirkan solusi yang diperoleh. d) Mengomunikasikan gagasan dengan simbol, tabel, diagram, atau media lain untuk memperjelas keadaan atau masalah. e) Memiliki sikap menghargai kegunaan Matematika dalam kehidupan, yaitu memiliki rasa ingin tahu, perhatian, dan minat dalam mempelajari
Matematika, serta sikap ulet dan percaya diri dalam pemecahan masalah.

Tahapan pelaksanaan pembelajaran dengan menggunakan model pembelajaran group investigation sebagai berikut (1) Mengidentifikasi topik dan membagi siswa ke dalam kelompok. Pada tahap ini guru memberikan kesempatan bagi siswa untuk memberi kontribusi apa yang akan mereka selidiki. Kelompok dibentuk berdasarkan heterogenitas.

Merencanakan tugas. Pada tahap ini kelompok akan membagi sub topik kepada seluruh anggota. Kemudian membuat perencanaan dari masalah yang akan diteliti, bagaimana proses dan sumber apa yang akan dipakai. (3) Membuat penyelidikan. Pada tahap ini siswa mengumpulkan, menganalisis dan mengevaluasi informasi, membuat kesimpulan dan mengaplikasikan bagian mereka ke dalam pengetahuan baru dalam mencapai solusi masalah kelompok. (4) Mempersiapkan tugas akhir. Pada tahap ini setiap kelompok mempersiapkan tugas akhir yang akan dipresentasikan di depan kelas. (5) Mempresentasikan tugas akhir. Pada tahap ini siswa mempresentasikan hasil kerjanya. Kelompok lain tetap mengikuti. (6) Evaluasi. Pada tahap ini para siswa memperoleh soal ulangan yang mencakup seluruh topik yang telah diselidiki dan dipresentasikan.

\section{Kerangka Berpikir}

Penerapan model pembelajaran

$\begin{array}{lcr}\text { group investigation } & \text { dalam } \\ \text { meningkatkan pengetahuan } & \text { dan } \\ \text { pemahaman siswa } & \text { untuk } \\ \text { menyelesaikan masalah } & \text { yang } \\ \text { berkaitan dengan data } & \text { dalam } \\ \text { pembelajaran Matematika } & \text { dapat } \\ \text { dilihat pada gambar } 1 . & \end{array}$




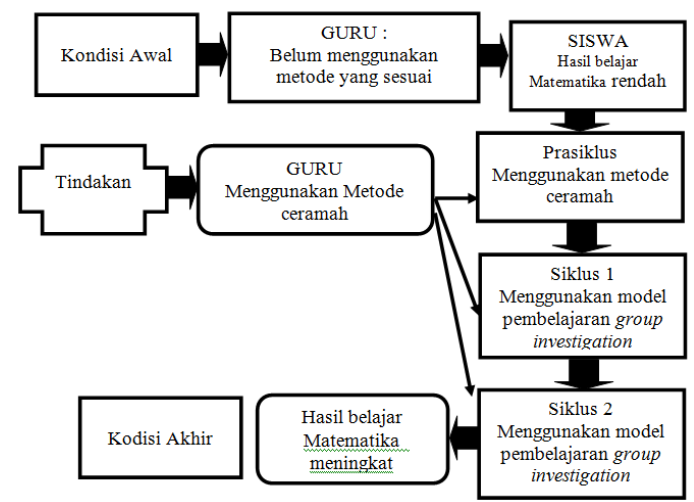

Gambar 1. Kerangka berfikir penelitian

\section{Hipotesis Tindakan}

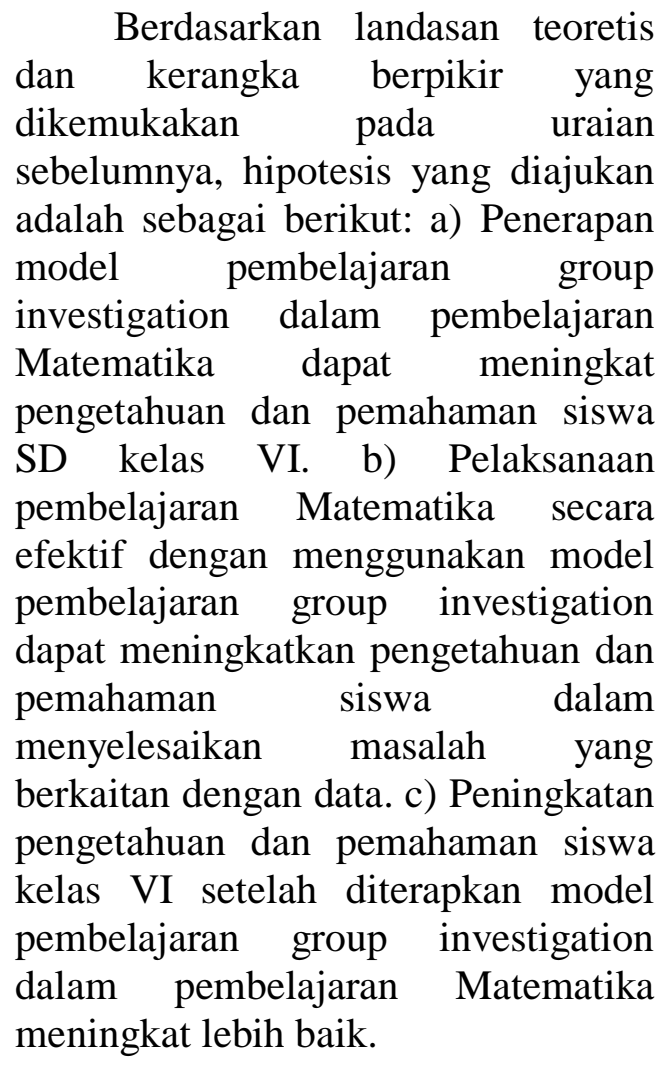

\section{METODE PENELITIAN}

\section{Tempat, Waktu, dan Subyek Penelitian}

Tempat penelitian di Sekolah Dasar Negeri Mororejo UPT Disdikpora Kecamatan Mlonggo Kabupaten Jepara dengan waktu pelaksanaan pada bulan Februari sampai dengan Juli 2018, dengan subjek penelitian sebanyak 25 siswa kelas 6.

\section{Desain Penelitian}

Desain dalam penelitian ini dilaksanakan dalam dua siklus masing-masing siklus melalui empat tahap yaitu: a) Tahap Perencanaan (Planning) dilakukan pengamatan awal terhadap situasi kelas dalam konteks situasi sekolah secara umum. Dari sini peneliti akan mendapatkan gambaran umum tentang masalah yang ada. Kemudian bersama kolaborator atau mitra peneliti melakukan pengamatan terhadap proses pembelajaran di kelas, dengan perhatian yang dicurahkan pada perilaku guru yang terkait dengan upaya mebantu siswa belajar dan perilaku siswa ketika proses pembelajaran berlangsung. b) Tahap Pelaksanaan (Acting) adalah tindakan yang dilakukan secara sadar dan terkendali, yang merupakan variasi praktik yang cermat dan bijaksana. Praktik diakui sebagai gagasan dalam tindakan dan tindakan itu digunakan sebagai pijakan bagi pengembangan tindakan-tindakan berikutnya, yaitu tindakan yang disertai niat untuk memperbaiki keadaan. PTK didasarkan atas pertimbangan teoritis dan empiris agar hasil yang diperoleh berupa peningkatan pembelajaran optimal. c) Tahap Pengamatan (Observing) berfungsi untuk mendokumentasikan pengaruh tindakan terkait. Observasi perlu direncanakan dan juga didasarkan dengan keterbukaan pandangan dan pikiran serta bersifat responsif. Objek observasi adalah seluruh proses tindakan terkait, pengaruhnya (yang disengaja dan tidak disengaja), keadaan dan kendala tindakan 
direncanakan dan pengaruhnya, serta persoalan lain yang timbul dalam konteks terkait. Observasi dalam PTK adalah kegiatan pengumpulan data yang berupa proses pembelajaran. d) Tahap Refleksi (Reflection) adalah mengingat dan merenungkan suatu tindakan persis seperti yang telah dicatat dalam observasi. Refleksi berusaha memahami proses, masalah, persoalan, dan kendala yang nyata dalam tindakan strategis. Refleksi biasanya dibantu oleh diskusi di antara peneliti dan kolaborator. Melalui diskusi, refleksi memberikan dasar perbaikan rencana. Refleksi (perenungan) merupakan kegiatan analisis, interpretasi dan eksplanasi (penjelasan) terhadap semua informasi yang diperoleh dari observasi atas pelaksanaan tindakan.

\section{Teknik Analisis Data}

Analisis data dilakukan secara deskriptif kualitatif. Analisis deskriptif untuk mengolah data nilai yang berupa kemampuan matematika yang dianalisis dengan pencapaian persentase. Hal ini dimaksudkan bahwa siswa dikatakan mampu menguasai materi jika mencapai tingkat penguasaan 75 atau lebih, serta tingkat keaktifan siswa dapat mencapai $75 \%$ atau lebih.

\section{HASIL DAN PEMBAHASAN}

Melalui pembelajaran kooperatif dengan metode Group Investigation suasana belajar terasa lebih efektif, kerjasama kelompok dalam pembelajaran ini dapat membangkitkan semangat siswa untuk memiliki keberanian dalam mengemukakan pendapat dan berbagi informasi dengan teman lainnya dalam membahas materi pembelajaran. Setelah diadakan analisis tes formatif pelaksanaan prasiklus siswa kelas VI hasilnya belum memuaskan sebab dari 25 siswa mengikuti tes formatif menunjukkan tingkat ketuntasan siswa baru $44 \%$ dan yang belum tuntas sebesar $56 \%$.

Pada pelaksanaan pembelajaran siklus 1 pada pembelajaran Matematika dengan materi memecahkan masalah yang berkaitan dengan data ke bentuk tabel, diagram, diagram garis, batang, dan lingkaran dan setelah hasil belajar siswa dianalisis melalui hasil monitoring selama tindakan berlangsung menunjukkan ada 18 siswa telah mampu menguasai materi yang disampaikan dengan baik atau telah mencapai tingkat ketuntasan belajar $72 \%$ sedangkan untuk 7 siswa yang lain belum mampu mencapai tingkat ketuntasan belajar.

Setelah diadakan perhitungan hasil pencapaian siswa dalam mengerjakan tes formatif pada siklus I didapat kategori nilai seperti tertuang pada tabel 1 sebagai berikut:

Tabel 1. Rekapitulasi Hasil Tes Formatif Siklus 1

\begin{tabular}{|c|c|c|c|c|c|c|c|c|c|c|}
\hline \multicolumn{6}{|c|}{ Frekuensi Perolehan Nilai Siswa } & \multirow{2}{*}{$\begin{array}{c}\text { Jumlah } \\
\text { Siswa }\end{array}$} & \multicolumn{4}{|c|}{ Banyak Siswa } \\
\hline 100 & 90 & 80 & 70 & 60 & 50 & & Tuntas & $\%$ & Tdk tuntas & $\%$ \\
\hline 9 & 6 & 3 & 4 & 3 & - & 25 & 18 & 72 & 7 & 28 \\
\hline
\end{tabular}

Selanjutnya untuk melihat sejauh mana, tingkat pencapaian nilai hasil rekapitulasi nilai tes formatif Matematika pada siklus 1 dapat dilihat pada diagram 1 . 


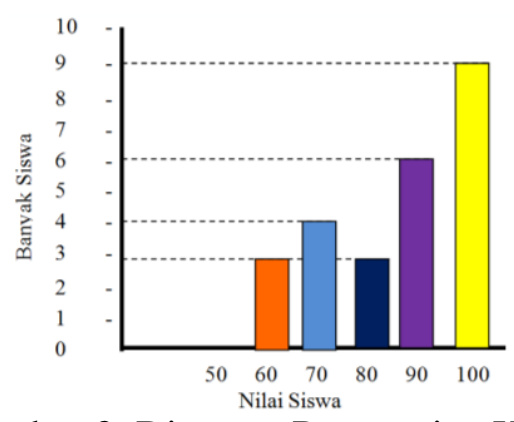

Gambar 2. Diagram Pencapaian Hasil

Belajar Siswa Siklus 1

Dari pelaksanaan penelitian tindakan kelas siklus 2 pada pembelajaran Matematika materi memecahkan masalah yang berkaitan dengan data ke bentuk tabel, diagram, diagram garis, batang, dan lingkaran nampak ada peningkatkan yang sangat berarti. Melalui hasil monitoring selama tindakan berlangsung dari 25 siswa kelas VI menunjukkan ada 24 siswa telah mampu mencapai tingkat ketuntasan belajar $96 \%$ dan 1 siswa belum mampu mencapai tingkat ketuntasan belajar $4 \%$. Melihat hasil belajar siswa pada siklus 2 nampak sudah melebihi batas kriteria ketuntasan minimal (KKM) lebih dari 75.

Setelah diadakan perhitungan hasil pencapaian siswa dalam mengerjakan tes formatif pada siklus 2 didapat kategori nilai seperti tertuang pada tabel 2 sebagai berikut:

Tabel 2. Rekapitulasi Hasil Tes Formatif Siklus 2

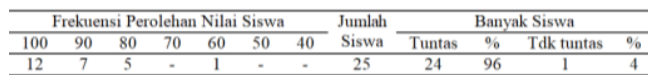

Berdasarkan rekapitulasi hasil tes formatif mata pelajaran Matematika untuk Kelas VI siklus 2 hasilnya sungguh sangat menggembirakan. Selanjutnya untuk melihat sejauh mana, tingkat pencapaian nilai hasil rekapitulasi nilai tes formatif Matematika pada siklus I dapat dilihat pada diagram 2.

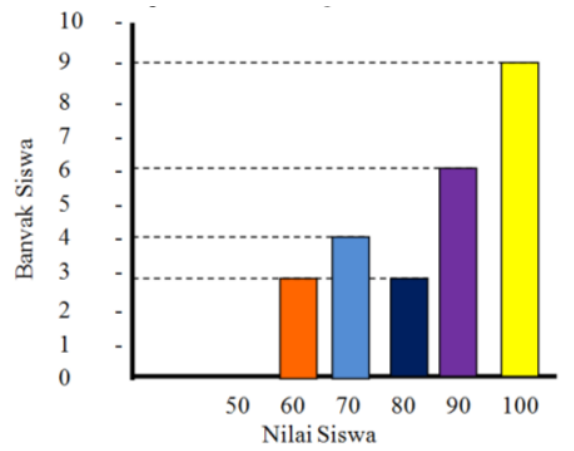

Gambar 3. Diagram Pencapaian Hasil Belajar Siswa Siklus 2

Setelah diadakan perbaikan pembelajaran dalam dua siklus terdapat kemajuan yang semakin meningkat. Agar lebih jelasnya penulis cantumkan data yang diperoleh selama 2 siklus perbaikan pembelajaran sebagai berikut:

Tabel 3. Hasil Penelitian dalam Dua Siklus

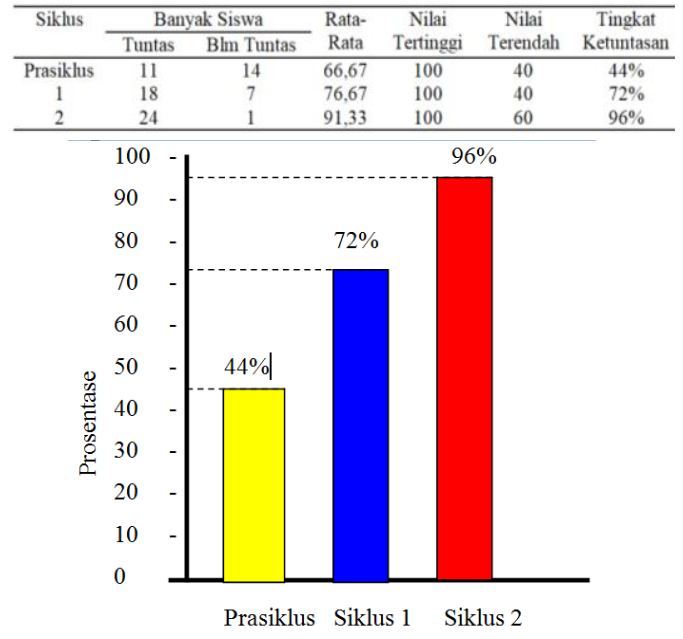

Gambar 4. Diagram Tingkat

Pencapaian Ketuntasan Belajar

\section{Pembahasan}

Peningkatan kualitas pendidikan Nasional ditentukan oleh beberapa hal, antara lain guru yang profesional dan kebijakan pemerintah yang mendukung tercapainya mutu Pendidikan Nasional, untuk mencapai 
tujuan pendidikan nasional seperti yang tercantum dalam UndangUndang Nomor 20 tahun 2003 tentang Sitem Pendidikan Nasional Pasal 3 dibutuhkan guru yang profesional. Guru yang profesional akan mampu melaskanakan proses pembelajaran dalam situasi edukaif yang aktif, kreatif, dan menyenangkan dan terjadi interaksi timbal balik antara guru dengan siswa dan siswa dengan siswa selama proses pembelajaran.

Sehubungan dengan itu, maka guru adalah figur manusia sebagai penentu keberhasilan pendidikan. Guru harus pandai dalam mendesain dan mengelola pembelajaran di kelas sehingga dapat mencapai keberhasilan yang maksimal.

Berdasarkan diskusi dan pembahasan bersama dengan teman sejawat dapat ditemukan berbagai masalah yang timbul antara lain:

\section{Siklus 1}

Pelaksanaan siklus 1 pada perilaku guru kurang menunjukkan hasil yang memuaskan, karena terbukti guru kurang persiapan dalam menyampaikan pembelajaran. Sebagai contoh tidak mampu menerapakan media pembelajaran beragam yang sudah dipersiapkan karena waktu pembelajaran dihabiskan untuk berceramah tentang materi pelajaran, materi belum disampaikan secara penuh, tidak memberi kesempatan kepada siswa untuk aktif membuat percobaan.

\footnotetext{
Langkah-langkah yang dipilih guru untuk mengatasi masalah tersebut adalah mencari informasi melalui buku dan meminta bimbingan kepada teman sejawat, serta
}

memberikan tugas kepada siswa berlatih dan mencoba dengan media pembelajaran yang sesuai.

Dengan demikian hasil belajar siswa belum maksimal sehingga guru harus mengambil langkah-langkah untuk mengatasi masalah tersebut antara lain: a) Membimbing siswa secara menyeluruh dengan menggunakan media pembelajaran yang beragam. b) Menerapkan media pembelajaran yang beragam dapat menjangkau seluruh siswa, sehingga setiap siswa aktif dalam pelaksanaan media pembelajaran tersebut. c) Menggunakan lembar kerja sebagai latihan yang harus didiskusikan bersama teman sekelas.

Pada perilaku siswa telah menunjukkan keberanian dalam mengajukan pendapat dan ingin mendiskusikan materi memecahkan masalah yang berkaitan dengan data ke bentuk tabel, diagram, diagram garis, batang, dan lingkaran.

\section{Siklus 2}

Pelaksanaan siklus 2 pada perilaku guru hasilnya nampak lebih menggembirakan dan benar-benar menunjukkan hasil yang sangat memuaskan, karena pada siklus 2 guru telah menggunakan media dan alat peraga yang lebih lengkap dan bervariasi dalam proses pembelajaran. Di samping penerapan pembelajaran dengan menggunakan media pembelajaran yang beragam telah nampak digemari siswa. Sebagai bukti siswa sangat antusias dalam memecahkan masalah yang berkaitan dengan data ke bentuk tabel, diagram, diagram garis, batang, dan lingkaran, yang hasilnya ada kemajuan yang signifikan terbukti hasil belajar dari siklus ke siklus berikut ada kemajuan 
yang memuaskan. Siklus 1 pencapaian tingkat ketuntasan siswa $66,67 \%$, dan pada siklus 2 meningkat menjadi $93,33 \%$.

Pada perilaku siswa juga sudah semakin ada kemajuan yang berarti. Interaksi siswa dengan guru tercipta harmonis, tidak ada rasa ketakutan, antara siswa dan siswa terjadi interaksi yang baik dan komunikatif, serta saling membimbing bagi siswa yang telah menguasai materi tentang memecahkan masalah yang berkaitan dengan data ke bentuk tabel, diagram, diagram garis, batang, dan lingkaran.

Pelaksanaan pembelajaran dari
siklus ke siklus berikutnya
menunjukkan hasil yang sangat
memuaskan, karena guru telah
menggunakan media dan alat peraga
yang lebih lengkap dan bervariasi
dalam proses pembelajaran tentang
memecahkan masalah yang berkaitan
dengan data ke bentuk tabel, diagram,
diagram garis, batang, dan lingkaran..
Pelaksanaan Prasiklus baru mencapai
$44 \%$, kemudian pada siklus 1
pencapaian tingkat ketuntasan siswa
$72 \%$, dan pada siklus 2 meningkat
menjadi $96 \%$.

\section{SIMPULAN}

Dari uraian di muka, maka dapat dibuat simpulan sebagai berikut:

1. Dengan penerapan model pembelajaran group investigation siswa mampu meningkatkan pengetahuan siswa dalam memecahkan masalah yang berkaitan dengan data ke bentuk tabel, diagram, diagram garis, batang, dan lingkaran.
2. Melalui media pembelajaran dapat membuktikan bahwa siswa dapat memecahkan masalah yang berkaitan dengan data ke bentuk tabel, diagram, diagram garis, batang, dan lingkaran.

3. Dengan melakukan model pembelajaran group investigation siswa mampu memecahkan masalah yang berkaitan dengan data ke bentuk tabel, diagram, diagram garis, batang, dan lingkaran.

4. Dengan tugas-tugas yang diberikan, siswa mampu membuat rangkuman sesuai dengan materi yang telah disajikan.

5. Dengan memperbanyak soal-soal latihan siswa meningkat pengetahuannya dalam memecahkan masalah yang berkaitan dengan data ke bentuk tabel, diagram, diagram garis, batang, dan lingkaran

6. Dalam proses pembelajaran guru melibatkan semua siswa sehingga mampu memecahkan masalah yang berkaitan dengan data ke bentuk tabel, diagram, diagram garis, batang, dan lingkaran.

7. Siswa aktif dan teliti dalam mengerjakan soal latihan sehingga dapat meningkatkan pengetahuan dan prestasi belajar.

8. Mengaktifkan siswa dalam melakukan diskusi dengan teman sebangku siswa mampu memecahkan masalah yang berkaitan dengan data ke bentuk tabel, diagram, diagram garis, batang, dan lingkaran. 
DAFTAR PUSTAKA

2003. Undang-Undang No. 20 tahun 2003 Tentang Sistem Pendidikan Nasional. Jakarta: Departemen Pendidikan Nasional.

Badan Standar Nasional Pendidikan, 2007. Standar Kompetensi dan Kompetensi Dasar Tingkat SD/MI. Jakarta: Depdiknas.

Clark. 1981. Cognitive Prespective Theory and Psyco Educational Design. California: University Of Southern California.
Sudjana. 1989. Dasar-dasar Proses Belajar Mengajar. Bandung: Sinar Baru.

Sudjana. 2002. Metode dan Teknik Pembelajaran Partisipatif. Bandung: Falah Production.

Tim Pengembang Kurikulum Jawa Tengah, 2008. Model-Model Pembelajaran. Semarang: Dinas P\&K Jawa Tengah. 